The $6^{\text {th }}$ Conf. of SSFOP “Sustainable Development of Ornamental, Medicinal and Aromatic

Plants Scope”, Cairo, Egypt, 1/3/2020

Scientific J. Flowers \& Ornamental Plants

www.ssfop.com/journal

ISSN: 2356-7864

doi: 10.21608/sjfop.2020.91396

\title{
EFFECT OF SOME HORMONAL TREATMENTS ON GROWTH AND CHEMICAL COMPOSITION OF RHAPHIOLEPIS UMBELLATA SHRUB
}

\author{
F.M. Saadawy; A.S. El-Fouly and A.W. Sayed
}

\begin{abstract}
Ornamental Plants and Landscape Gardening Res. Dept., Hort. Res. Inst., ARC, Giza, Egypt
\end{abstract}
\begin{abstract}
A pot experiment was consummated on Rhaphiolepis umbellata seedlings grown under seran greenhouse at Al-Zohriya Garden, Hort. Res. Inst., ARC, Giza, Egypt during the two consecutive seasons 2017 and 2018, to study effects of five foliar spray treatments of a mixture containing three growth regulators (PGR), at the same concentration for each, on plant growth and chemical composition. The three-tested PGR were NAA, GA $\mathrm{G}_{3}$ and $\mathrm{BA}$, while the five concentrations for each were 0 (control treatment), 100, 200, 300 and $400 \mathrm{ppm}$. Obtained results indicated that, generally, all recorded vegetative and root growth traits; i.e., plant height, stem diameter, numbers of branches and number of leaves/plant, leaf area, root length and number of roots/plant increased significantly under the effect of all tested PGR treatments, compared to the control plants. The highest increases in this regard were recorded in plants sprayed with PGR at $200 \mathrm{ppm}$, while the least values were found in the untreated control

plants, followed by plants sprayed with the highest PGR concentration of $400 \mathrm{ppm}$ for the two seasons. The same trend was noticed in respect of leaf chemical constituents, as plants that recorded the highest vegetative and root growth (treated 200 ppm PGR) also contained the highest values of total chlorophyll and carotenoids (mg/g f.w.) as well as percentages of total carbohydrate, $\mathrm{N}, \mathrm{P}$ and $\mathrm{K}$ in leaf tissues. Accordingly, it could be recommended to apply the mixture of these three growth regulators $200 \mathrm{ppm}$ on seedlings of Rhaphiolepis umbellata, two times monthly during the growing season to get the best plant growth and quality.
\end{abstract}

Scientific J. Flowers \& Ornamental Plants, 7(1):45-52 (2020).

Received:

$7 / 1 / 2020$

Accepted:

$4 / 2 / 2020$

Key words: Rhaphiolepis umbellata, foliar spraying, plant growth regulators, $\mathrm{NAA}, \mathrm{GA}_{3}$, $\mathrm{BA}$.

\section{INTRODUCTION}

Ornamental plants hold an important status in the horticultural industry of the world (Sajjad et al., 2017). The flowering shrub Rhaphiolepis umbellata is one of the rarest unknown plants despite the beauty of its flowers and vegetative growth. Its growth is very slow. It belongs to Fam. Rosaceae, native to Korea and Japan. The common name hawthorn is often called "Yeddo hawthorn". This species vary in size, some reaching $1.0-1.5 \mathrm{~m}$.

The exogenous application of plant growth regulators plays an important role in the modern production of ornamentals as they help to improve the different economically important and market desirable characteristics of them. The use of plant growth regulators is being widely practiced by the commercial growers of ornamental 
plants as a part of cultural practice. Bergstrand (2017) reported that chemical plant growth regulators (PGRs) are used in the production of ornamental potted and bedding plants, as growth control is needed for maximizing production per unit area, reducing transportation costs and to obtain a desired visual quality. Plant growth regulators consist of a large group of naturally occurring or synthetically produced organic chemicals and considered as helping tool in ornamentals production system. There are various factors contributing to the efficacy of plant growth regulators.

Benzyladenine (BA) is a synthetic cytokinin comprises the N6-substituted aminopurine. It stimulates protein synthesis. It is perhaps for this reason can promote the maturation of chloroplasts (Taiz and Zeiger, 2002). Taiz and Zeiger (2010) stated that although apical dominance may be determined primarily by auxin; physiological studies indicated that cytokinins play important role in initiating the growth of lateral buds. Direct application of cytokinins to the axillary buds of many species stimulates cell division activity.

Gibberellic acid $\left(\mathrm{GA}_{3}\right)$ regulates stem elongation, stimulates plant growth and development, also, it plays important roles in transition from meristem to shoot growth, juvenile to adult leaf stage, vegetative to flowering and determines sex expression along with an interaction of different environmental factors, viz. light, temperature and water (Gupta and Chakrabarty, 2013).

Naphthaleneacetic acid (NAA) is an organic compound with the formula $\mathrm{C}_{10} \mathrm{H}_{7} \mathrm{CH}_{2} \mathrm{CO}_{2} \mathrm{H}$. NAA is a plant growth regulator belongs to the auxin group and it is an ingredient in many commercial postharvest horticultural products. It is also a rooting agent, used for enhancing vegetative propagation of plants by stem and leaf cuttings (Dimitrios et al., 2008 and Mohammed et al., 2009).

This research aimed to overcome the problem of slow growth in Rhaphiolepis umbellata, which limits its spread in gardens and nurseries despite the beauty of flowers and vegetative growth.

\section{MATERIALS AND METHODS}

A pot experiment was consummated on Rhaphiolepis umbellata plant grown under seran conditions at Al-Zohriya Garden, Hort. Res. Inst., ARC, Giza, Egypt during 2017 and 2018 consecutive seasons. The research aimed to study effects of five foliar spray treatments of mixture containing three plant growth regulators (PGR) of NAA, GA 3 and $\mathrm{BA}$ at the same concentration for each, on plant growth and quality as well as its chemical composition. The tested PGR concentrations were $0,100,200,300$ or 400 ppm for each regulator.

On May $1^{\text {st }}$ of the two experimental seasons, three-month-old uniform seedlings of Rhaphiolepis umbellata were carefully transplanted in $20-\mathrm{cm}$-diameter plastic pots filled with $3.4 \mathrm{~kg}$ potting mixture containing sand + clay at $1: 1(\mathrm{v} / \mathrm{v})$, analysis of which is shown in Table (a).

Five foliar spray treatments of PGR mixture containing NAA (soluble in water), $\mathrm{GA}_{3}$ and $\mathrm{BA}$ at equal concentrations for each were tested as follows:

- Tap water (PGR 0) as a control.

- PGR (NAA, GA 3 and BA) at 100 ppm for each.

- PGR (NAA, GA $\mathrm{GA}_{3}$ and BA) at 200 ppm for each.

- PGR (NAA, GA $\mathrm{GA}_{3}$ and BA) at 300 ppm for each.

- PGR (NAA, GA 3 and BA) at 400 ppm for each.

Table a. Physical and chemical analysis of the used potting mixture (sand+ clay 1:1 v/v) during 2017 and 2018 seasons.

\begin{tabular}{cccccccccccccc}
\hline \multicolumn{2}{c}{$\begin{array}{c}\text { Particle size distribution (\%) } \\
\text { Sand }\end{array}$} & Silt & Clay & $\mathbf{C a O}_{3}$ & $\mathbf{( d s / m )}$ & $\mathbf{p H}$ & \multicolumn{3}{c}{ Cations (meq./l) } & \multicolumn{3}{c}{ Anions (meq./l) } \\
\hline 69.9 & 20.6 & 9.5 & 25.0 & 6.6 & 7.88 & 17.8 & 14.2 & 33.1 & 0.9 & 2.1 & - & 5.5 & 85.4 \\
\hline
\end{tabular}




\section{Method of preparing PGR mixture:}

The PGR solution was prepared by solving a known weight of BA $(0.1,0.2,0.3$, and $0.4 \mathrm{~g}$ for the four concentrations used in this study) in a few drops of $\mathrm{HCl}$ acid (0.5 $\mathrm{N})$ to facilitate solving, then completed with tap water to the volume of $1000 \mathrm{ml}$. NAA and $\mathrm{GA}_{3}$ (as quick solvents in water ) were added thereafter (at the abovenamed weights) to the BA solution $(1000 \mathrm{ml})$, shaked-up, and then the final solution containing $\mathrm{BA}, \mathrm{NAA}$, and $\mathrm{GA}_{3}$ (at equal concentration for each) was sprayed on plant foliage till run-off after adding a little of spreading material.

Plants were treated two weeks after transplanting (on May $15^{\text {th }}$ for the two tested seasons) with foliar spraying two times monthly. Spraying was achieved using handheld sprayer to achieve coverage of the leaves and stems to enhance plant growth throughout the experimental period.

Treatments were set up in simple experiment with the above-mentioned five treatments of PGR foliar sprays in a completely randomized design. Treatments were replicated thrice, and each replicate contained three plants. Plants of all treatments were fertilized one time monthly with the irrigation process using a commercial fertilizer containing NPK (20:20:20) at $1 \mathrm{~g} / \mathrm{l}$ till the end of experiment on November $15^{\text {th }}$. All plants received the usual necessary agricultural practices whenever needed.

\section{Recorded data:}

On November $15^{\text {th }}$, for the two tested seasons, the experiment was terminated and the following data were recorded:

Vegetative growth was assessed as plant height $(\mathrm{cm})$, stem diameter $(\mathrm{cm})$, numbers of branches and number of leaves/plant, leaf area $\left(\mathrm{cm}^{2}\right)$ root length $(\mathrm{cm})$, in addition to fresh and dry weights of top growth and roots/plant). Photosynthetic pigments of total chlorophyll $(\mathrm{a}+\mathrm{b})$ and carotenoids $(\mathrm{mg} / \mathrm{g}$ f.w.) were determined in fresh leaf samples according to the method described by Moran
(1982). Total carbohydrates content, and percentages of $\mathrm{N}, \mathrm{P}$ and $\mathrm{K}$ were determined in dried leaf samples at $70{ }^{\circ} \mathrm{C}$ for 72 hours according to methods of Dubois et al. (1966), Pregl (1945), Wide et. al. (1985) and Jackson (1973), respectively.

\section{Statistical analyses:}

Collected data were subjected to statistical analyses using SAS Institute Program (2009) and the differences among treatments were compared according to Duncan's New Multiples Range Test. (Steel and Torrie, 1980).

\section{RESULTS AND DISCUSSION}

\section{Effect of PGR treatments on:}

\section{Vegetative and root growth parameters:}

Data in Tables 1 and 2 and Fig. 1 cleared that in general, values of all shoot and root growth traits (plant height, stem diameter, numbers of branches and leaves/plant, leaf area, root length, number of roots/plant, in addition to fresh and dry weights of top and root growth) increased significantly under the effect of all tested PGR's treatments compared to the control. Superiority in all characters in the two seasons was confined to using PGR's at $200 \mathrm{ppm}$, followed by PGR's at 300 ppm, in both seasons. PGR's at 100 and $400 \mathrm{ppm}$ acquired the third and the fourth positions, respectively.

\section{Leaf chemical composition:}

Data in Tables 3 and 4 exhibited that all tested PGR treatments markedly increased total chlorophylls and carotenoid pigments (mg/g f.w.) as well as percentages of total carbohydrate, $\mathrm{N}, \mathrm{P}$ and $\mathrm{K}$ in leaf tissues. The highest values in this respect were recorded in plants received PGR's at 200 ppm, followed by PGR's at $300 \mathrm{ppm}$. On the other hand, the lowest contents were found in plants sprayed with PGR's at $100 \mathrm{ppm}$ and PGR's at $400 \mathrm{ppm}$. These results were confirmed during the two experimental seasons. 
F.M. Saadawy et al.

Table 1. Effect of foliar spray of plant growth regulators on some vegetative and root growth traits of Rhaphiolepis umbellata plant during 2017 and 2018 seasons.

\begin{tabular}{|c|c|c|c|c|c|c|c|}
\hline $\begin{array}{l}\text { Treatments } \\
\text { (PGR levels) }\end{array}$ & $\begin{array}{l}\text { Plant length } \\
\text { (cm) }\end{array}$ & $\begin{array}{c}\text { Stem } \\
\text { diameter } \\
(\mathrm{cm})\end{array}$ & $\begin{array}{l}\text { branches } \\
\text { No./plant }\end{array}$ & $\begin{array}{c}\text { leaves } \\
\text { No./plant }\end{array}$ & $\begin{array}{l}\text { leaf area } \\
\left(\mathrm{cm}^{2}\right)\end{array}$ & $\begin{array}{l}\text { root length } \\
\text { (cm) }\end{array}$ & $\begin{array}{c}\text { roots } \\
\text { No./plant }\end{array}$ \\
\hline \multicolumn{8}{|c|}{ First season: 2017} \\
\hline Control & $13.13 \mathrm{~d}$ & $0.28 \mathrm{~d}$ & $1.00 \mathrm{c}$ & $15.67 \mathrm{c}$ & $5.68 \mathrm{~d}$ & $17.94 \mathrm{~d}$ & $12.67 \mathrm{~d}$ \\
\hline PGR 100 ppm & $22.74 \mathrm{bc}$ & $0.40 \mathrm{c}$ & $2.00 \mathrm{~b}$ & $26.67 \mathrm{~b}$ & $12.03 \mathrm{~b}$ & $29.83 \mathrm{~b}$ & $22.33 \mathrm{bc}$ \\
\hline PGR 200 ppm & $35.37 \mathrm{a}$ & $0.73 \mathrm{a}$ & $4.33 \mathrm{a}$ & $61.33 \mathrm{a}$ & $14.52 \mathrm{a}$ & $34.47 \mathrm{a}$ & 36.33 a \\
\hline PGR 300 ppm & $29.33 \mathrm{ab}$ & $0.57 \mathrm{~b}$ & $2.33 \mathrm{~b}$ & 53.67 a & $11.24 \mathrm{~b}$ & $29.30 \mathrm{~b}$ & $27.67 \mathrm{~b}$ \\
\hline PGR 400 ppm & $20.00 \mathrm{~cd}$ & $0.33 \mathrm{~cd}$ & $1.00 \mathrm{c}$ & 23.33 bc & $8.09 \mathrm{c}$ & 25.33 c & 20.00 c \\
\hline \multicolumn{8}{|c|}{ Second season: 2018} \\
\hline Control & $15.74 \mathrm{e}$ & $0.30 \mathrm{~d}$ & $1.00 \mathrm{c}$ & $19.67 \mathrm{~d}$ & $6.26 \mathrm{c}$ & $20.27 \mathrm{~d}$ & $13.33 \mathrm{~d}$ \\
\hline PGR 100 ppm & $23.80 \mathrm{c}$ & $0.42 \mathrm{c}$ & $2.00 \mathrm{~b}$ & $33.67 \mathrm{c}$ & $12.06 \mathrm{~b}$ & $48.10 \mathrm{a}$ & $23.33 \mathrm{bc}$ \\
\hline PGR 200 ppm & $35.57 \mathrm{a}$ & $0.77 \mathrm{a}$ & $5.00 \mathrm{a}$ & $74.00 \mathrm{a}$ & 14.63 a & $39.73 \mathrm{ab}$ & 39.67 a \\
\hline PGR 300 ppm & $32.17 \mathrm{~b}$ & $0.63 \mathrm{~b}$ & $2.67 \mathrm{~b}$ & $54.67 \mathrm{~b}$ & $13.51 \mathrm{a}$ & $31.00 \mathrm{bc}$ & $28.33 \mathrm{~b}$ \\
\hline PGR 400 ppm & $20.97 d$ & $0.41 \mathrm{c}$ & $1.00 \mathrm{c}$ & $27.00 \mathrm{~cd}$ & $11.86 \mathrm{~b}$ & $25.97 \mathrm{~cd}$ & $21.33 \mathrm{c}$ \\
\hline
\end{tabular}

Means having the same letter/s within a column are not significantly different according to Duncan's Multiple Range Test at 5\% level. PGR $=$ NAA, GA3 and BA.

Table 2. Effect of foliar spray of plant growth regulator treatments on top and root fresh and dry weights of Rhaphiolepis umbellata plant during 2017 and 2018 seasons.

\begin{tabular}{|c|c|c|c|c|}
\hline $\begin{array}{l}\text { Treatments } \\
\text { (PGR levels) }\end{array}$ & $\begin{array}{c}\text { Top fresh weight } \\
\text { (g) }\end{array}$ & $\begin{array}{c}\text { Top dry weight } \\
\text { (g) }\end{array}$ & $\begin{array}{l}\text { Root fresh weight } \\
\text { (g) }\end{array}$ & $\begin{array}{l}\text { Root dry weight } \\
\text { (g) }\end{array}$ \\
\hline \multicolumn{5}{|c|}{ First season: 2017} \\
\hline Control & $8.00 \mathrm{~d}$ & $1.23 \mathrm{~d}$ & $1.14 \mathrm{~d}$ & $0.34 \mathrm{c}$ \\
\hline PGR 100 ppm & $15.51 \mathrm{c}$ & $4.09 \mathrm{c}$ & $1.69 \mathrm{~cd}$ & 0.87 c \\
\hline PGR 200 ppm & $40.84 \mathrm{a}$ & $14.57 \mathrm{a}$ & $10.74 \mathrm{a}$ & $5.40 \mathrm{a}$ \\
\hline PGR 300 ppm & $30.20 \mathrm{~b}$ & $11.45 \mathrm{~b}$ & $6.95 \mathrm{~b}$ & $3.25 \mathrm{~b}$ \\
\hline PGR 400 ppm & $12.98 \mathrm{c}$ & $4.23 \mathrm{c}$ & $3.34 \mathrm{c}$ & $0.83 \mathrm{c}$ \\
\hline
\end{tabular}

Second season: 2018

$\begin{array}{lcccc}\text { Control } & 8.87 \mathrm{~d} & 1.51 \mathrm{c} & 1.15 \mathrm{~d} & 0.61 \mathrm{c} \\ \text { PGR } 100 \text { ppm } & 16.51 \mathrm{c} & 4.70 \mathrm{~b} & 1.82 \mathrm{~cd} & 0.96 \mathrm{c} \\ \text { PGR } 200 \text { ppm } & 42.67 \mathrm{a} & 15.01 \mathrm{a} & 11.63 \mathrm{a} & 5.83 \mathrm{a} \\ \text { PGR } 300 \text { ppm } & 31.06 \mathrm{~b} & 13.46 \mathrm{a} & 7.37 \mathrm{~b} & 3.29 \mathrm{~b} \\ \text { PGR } 400 \text { ppm } & 12.94 \mathrm{~cd} & 7.03 \mathrm{~b} & 3.69 \mathrm{c} & 0.86 \mathrm{c}\end{array}$

Means having the same letter/s within a column are not significantly different according to Duncan's Multiple Range Test at 5\% level. PGR = NAA, GA3 and BA. 


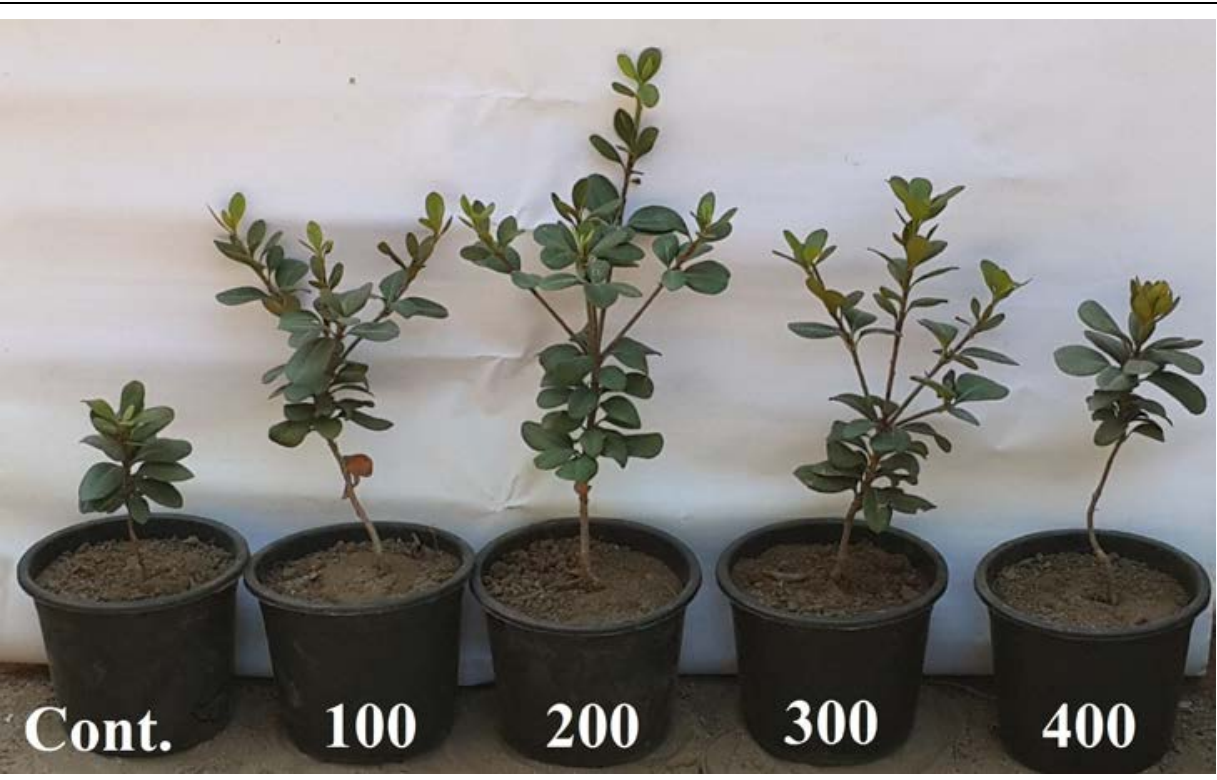

Fig. 1. Effect of foliar spraying of plant growth regulators of NAA, GA3 and BA on Rhaphiolepis umbellata seedlings growth.

Treatments from left to right: control, plants sprayed with PGR at $100 \mathrm{ppm}$ for each, spray with PGR at 200 ppm for each, spray with PGR at 300 ppm for each and spray with PGR at 400 ppm for each.

Table 3. Effect of foliar spray of plant growth regulator (PGR) treatments on leaf contents of total chlorophyll and carotenoids contents in leaf tissues of Rhaphiolepis umbellata during 2017 and 2018 seasons.

\begin{tabular}{lcc}
\hline $\begin{array}{c}\text { Treatments } \\
\text { (PGR levels) }\end{array}$ & $\begin{array}{c}\text { Total chlorophyll content } \\
\text { (mg/g f. w.) }\end{array}$ & $\begin{array}{c}\text { Carotenoids content } \\
\text { (mg/g f. w.) }\end{array}$ \\
\hline Tontrol & The first season: 2017 & \\
PGR 100 ppm & $2.05 \mathrm{e}$ & $0.27 \mathrm{~b}$ \\
PGR 200 ppm & $2.37 \mathrm{c}$ & $0.39 \mathrm{ab}$ \\
PGR 300 ppm & $3.20 \mathrm{a}$ & $0.41 \mathrm{a}$ \\
PGR 400 ppm & $2.56 \mathrm{~b}$ & $0.41 \mathrm{a}$ \\
\hline & $2.31 \mathrm{~d}$ & $0.29 \mathrm{ab}$ \\
Control & The second season:2018 & \\
PGR 100 ppm & $2.48 \mathrm{e}$ & $0.28 \mathrm{c}$ \\
PGR 200 ppm & $2.69 \mathrm{c}$ & $0.44 \mathrm{~b}$ \\
PGR 300 ppm & $3.28 \mathrm{a}$ & $0.49 \mathrm{a}$ \\
PGR 400 ppm & $2.79 \mathrm{~b}$ & $0.49 \mathrm{a}$ \\
\hline
\end{tabular}

Means having the same letter/s within a column are not significantly different according to Duncan's Multiple Range Test at 5\% level. PGR $=$ NAA, GA3 and BA. 
F.M. Saadawy et al.

Table 4. Effect of foliar spray of plant growth regulator (PGR) treatments on some leaf chemical composition of Rhaphiolepis umbellata during 2017 and 2018 seasons.

\begin{tabular}{lcccc}
\hline \multicolumn{1}{c}{$\begin{array}{c}\text { Treatments } \\
\text { (PGR levels) }\end{array}$} & $\begin{array}{c}\text { Total } \\
\text { carbohydrate } \%\end{array}$ & $\begin{array}{c}\text { Nitrogen } \\
\text { \% }\end{array}$ & $\begin{array}{c}\text { Phosphorus } \\
\text { \% }\end{array}$ & $\begin{array}{c}\text { Potassium } \\
\text { \% }\end{array}$ \\
\hline Control & \multicolumn{3}{c}{ The first season: 2017 } \\
PGR 100 ppm & $13.95 \mathrm{~d}$ & $1.20 \mathrm{~d}$ & $0.14 \mathrm{c}$ & $1.24 \mathrm{c}$ \\
PGR 200 ppm & $21.15 \mathrm{~b}$ & $1.61 \mathrm{bc}$ & $0.25 \mathrm{~b}$ & $1.65 \mathrm{ab}$ \\
PGR 300 ppm & $24.47 \mathrm{a}$ & $2.17 \mathrm{a}$ & $0.43 \mathrm{a}$ & $1.82 \mathrm{a}$ \\
PGR 400 ppm & $22.26 \mathrm{ab}$ & $1.75 \mathrm{~b}$ & $0.31 \mathrm{~b}$ & $1.65 \mathrm{ab}$ \\
\hline & $18.28 \mathrm{c}$ & $1.50 \mathrm{c}$ & $0.16 \mathrm{c}$ & $1.40 \mathrm{bc}$ \\
\hline Control & & The second season: 2018 & & \\
PGR 100 ppm & $16.89 \mathrm{e}$ & $1.37 \mathrm{c}$ & $0.46 \mathrm{~d}$ & $2.11 \mathrm{~d}$ \\
PGR 200 ppm & $25.41 \mathrm{c}$ & $1.63 \mathrm{c}$ & $0.80 \mathrm{bc}$ & $2.28 \mathrm{bc}$ \\
PGR 300 ppm & $33.21 \mathrm{a}$ & $2.42 \mathrm{a}$ & $1.00 \mathrm{a}$ & $2.46 \mathrm{a}$ \\
PGR 400 ppm & $29.17 \mathrm{~b}$ & $2.03 \mathrm{~b}$ & $0.86 \mathrm{ab}$ & $2.41 \mathrm{ab}$ \\
\hline
\end{tabular}

Means having the same letter/s within a column are not significantly different according to Duncan's Multiple Range Test at 5\% level. PGR = NAA, GA 3 and BA.

\section{DISCUSSION}

Khandaker et al. (2017) found that the application of $25 \mathrm{mg} / \mathrm{l}$ NAA significantly increased plant height, number of roots and total soluble solid content of Mokara Chark kuan orchid plants. However, there was no significant effect on number of leaves, chlorophyll content and number of flowers. Hakan and Kerim (2013) found that auxin group hormones (IAA, IBA, and NAA) affected morphological characteristics of the newly generated plants, especially root generation. Nisha et al. (2012) studied the potential effect of benzylaminopurine (BAP) on Dendrobium hybrid (Dendrobium Angel White). Plantlets were subjected to spray containing different BAP concentrations. They found that the application of BAP increased number of produced leaves per plant. Currey and Erwin (2012) assessed the efficacy of foliar spray applications of benzyladenine (75-300 ppm) on stem elongation and branching of 11 kalanchoe species. They observed that benzyladenine increased number of branches for several species. Gupta and Chakrabarty (2013) stated that gibberellic acid is a plant hormone enhances plant growth and development. Gibberellins stimulate seed germination, transitions from meristem to shoot growth, juvenile to adult leaf stage and vegetative to flowering as well as determine sex expression and grain development along with an interaction of different environmental factors, viz. light, temperature and water. The major site of bioactive GA is stamens that influence male flower production and pedicel growth. Malgorzata and Małgorzata (2013) studied the effect of gibberellic acid $\left(\mathrm{GA}_{3}\right)$ on growth and flowering of Ajania pacifica 'Bea'. They observed that double spraying with $\mathrm{GA}_{3}$ accelerated buds development, thus shortened the cultivation time by about two days. Treatment with $\mathrm{GA}_{3}$ at $500 \mathrm{mg} / \mathrm{l}$ stimulated shoot elongation more than with $\mathrm{GA}_{3}$ at $250 \mathrm{mg} / \mathrm{l}$. Abdel-Moniem et al. (2014) advised to spray the foliage of spindle tree (Euonymus japonicus cv. Aureus) with $\mathrm{GA}_{3}$ at $300 \mathrm{ppm}$ combined with a liquid 
fertilizer at $2 \mathrm{ml} / \mathrm{l}$ for the best growth performance of such foliage pot plant. Also, they noticed that all vegetative and root growth parameters improved markedly with individual application of $\mathrm{GA}_{3}$ at $300 \mathrm{ppm}$, as this treatment gave higher growth compared to the control plants. Spraying with or $\mathrm{GA}_{3}$ at $200 \mathrm{ppm}$ improved some growth traits. Sardoei (2014) evaluated the effect of $\mathrm{GA}_{3}$ and BAP, at 0,100 and $200 \mathrm{mg} / \mathrm{l}$ on Ficus benjamina, Schefflera arboricola and Dizigotheca elegantissima plants at pot cultivation conditions. He found that the tallest plants belonged to $200 \mathrm{mg} / \mathrm{l} \mathrm{GA}_{3}+$ $200 \mathrm{mg} / \mathrm{l} \mathrm{BAP,}$ while the shortest ones belonged to the control treatment.

Accordingly, it could be recommended to spray three-months-old seedlings of Rhaphiolepis umbellata with a mixture of these three growth regulators at $200 \mathrm{ppm}$ for each, two times monthly to get the best plant growth and quality.

\section{REFERENCES}

Abdel-Moniem, A.M.; El-Fouly, A.S. and Shahin, S.M. (2014). Response of Euonymus japonicus Thunb cv. "Aureus" plant to some fertilization treatments, gibberellic acid and their interactions. Minufiya J. Agric. Res., 39(3/2):10591069.

Bergstrand, K.I. (2017). Methods for growth regulation of greenhouse produced ornamental pot- and bedding plants - a current review. Folia Hort., 29(1):63-74.

Currey, C.J. and Erwin, J.E. (2012). Foliar applications of plant growth regulators affect stem elongation and branching of 11 kalanchoe species. HortTech., 22(3):338-344.

Dimitrios, P.N.; Tzanetos, I.C.; Georgia, P.N. and Nikos, P. (2008). A portable sensor for the rapid detection of naphthalene acetic acid in fruits and vegetables using stabilized in air lipid films with incorporated auxin-binding protein 1 receptor. Talanta,77:786-792.
Dubois, M.; Smith, F.; Illes, K.A.; Hamilton, J.K. and Rebers, P.A. (1966). Colorimetric method for determination of sugars and related substances. Ann. Chem., 28(3):350-356.

Gupta, R. and Chakrabarty, S.K. (2013). Gibberellic acid in plant, still a mystery unresolved. Plant Signaling and Behavior, 8(9):1-5.

Hakan, S. and Kerim, G. (2013). Effects of IAA, IBA, NAA, and $\mathrm{GA}_{3}$ on rooting and morphological features of Melissa officinalis L. stem cuttings. The Scientific World Journal, Hindawi Publishing Corporation, 5 p. http://dx. doi.org/10.1155/2013/909507

Jackson, M.H. (1973). Soil Chemical Analysis, Prentice Hall of India Private Limited M-97, New Delhi, India, 498 p.

Khandaker, M.K.; Mohd, Z.M.R.; Nik, N.N. and Nashriyah, M. (2017). Effects of naphthalene acetic acid (NAA) on the plant growth and sugars effects on the cut flowers Mokara Chark Kuan orchid. Biosci. J., Uberlândia, 33(1):19-30.

Małgorzata, Z. and Małgorzata, A. (2013). Gibberellic acid effect on growth and flowering of Ajania pacifica Nakai Bremer Et Humphries. J. of Hort. Res., 21(1):21-27.

Mohammed, S.; Hossain, A.B.M.S.; Normaniza, O.; Nasrulhaq, A.B. and Moneruzzaman, K.M. (2009). The effects of naphthaleneacetic acid and gibberellic acid in prolonging bract longevity and delaying discoloration of Bougainvillea spectabilis. Biotchnology, 8(3):343-350.

Moran, R. (1982). Formula for determination of chlorophyllous pigment extracted with N, N-dimethyl formamide. Plant Physiol, 69:1376-81.

Nisha, N.; Tee, C.S. and Maziah, M. (2012). Effect of 6-benzylaminopurine on flowering of a Dendrobium orchid. Aust. J. of Crop Sci., 6(2):225-231. 
F.M. Saadawy et al.

Pregl, F. (1945). Quantitative Organic Micro-Analysis $4^{\text {th }}$ Ed. J \& A, Churchill, Ltd., London, pp. 203-209.

Sajjad, Y.; Jaskani, M.J.; Asif, M. and Qasim, M. (2017). Application of plant growth regulators in ornamental plants: A review. Pak. J. Agri. Sci., 54(2):327-333.

Sardoei, A.S. (2014). Plant growth regulators effects on the growth and photosynthetic pigments on three indoor ornamental plants. Euro. J. Exp. Bio., 4(2):311-318.

SAS Institute. (2009). SAS/SAT User`s Guides: Statistics., Veers. 9, SAS. Institute Inc. Cary, N.C., USA.

Steel, R.G.D. and Torrie, J.H. (1980). Principles and Procedures of Statistics.
McGraw Hill Book Co., Inc., New York, pp. 377-400.

Taiz, L. and Zeiger, E. (2002). Plant Physiology, Third Edition. Sinauer Associates, Inc. Publishers. Sunderland, pp. 67-86.

Taiz, L and Zeiger, E. (2010). Plant Physiology, Fifth Edition. Sinauer Associates, Inc. Publishers. Sunderland, 623 p.

Wide, S.A.; Corey, R.B.; Lyer, J.G. and Vioget, G. (1985). Soil and Plant Analysis for Tree Culture, $3^{\text {rd }}$ Ed., Oxford, IBH Publishing Co., New Delhi, pp. 93-116.

\section{تأثير بعض المعاملات الهرمونية على النمو والتركيب الكيماوى لشجيرة الر افيوليبيس (Rhaphiolepis umbellata)}

$$
\text { قسم بحوث الزينة وتتسيق الحدائق، معهد بحدي العليم سعاوي، أمل صلاح الفولي، أحمد و هبه سيد البساتين، مركز البحوث الزر اعية، الجيزة، مصر }
$$

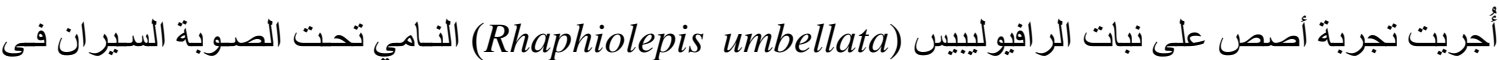

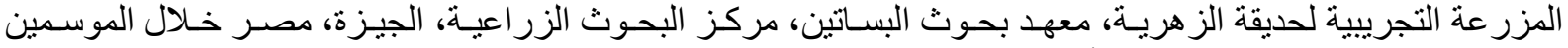

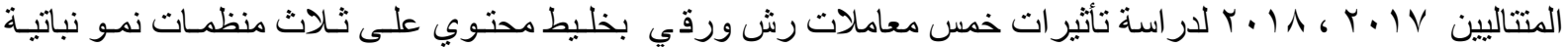

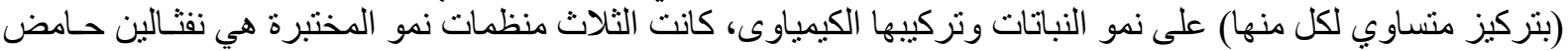

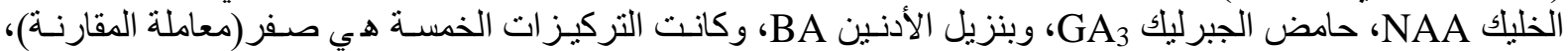

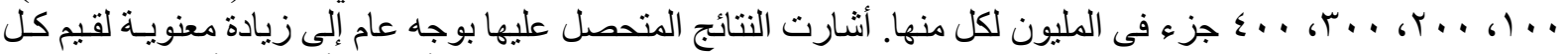

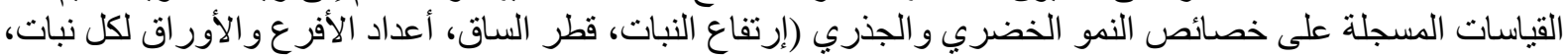

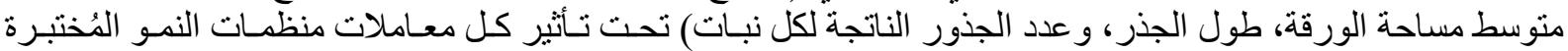

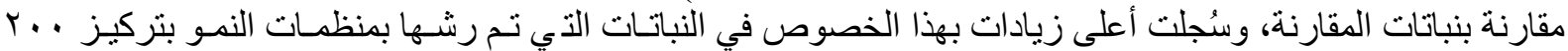

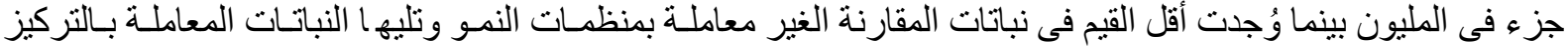

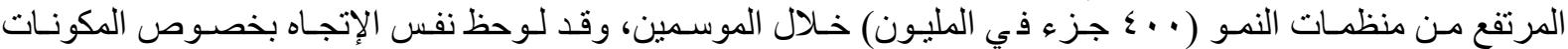

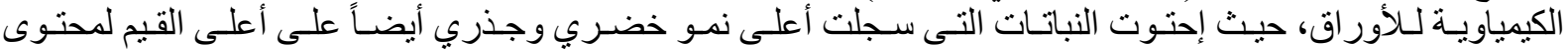

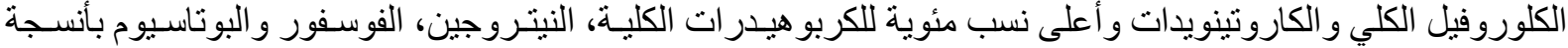

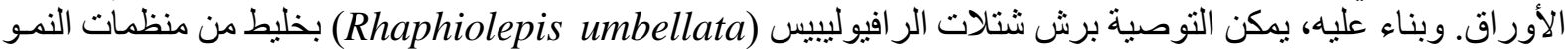

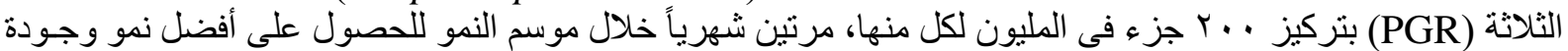

